\title{
CLARIFICATIONS ON THE PRINCIPLE OF THE AUTONOMY IN LOCAL PUBLIC ADMINISTRATION MANAGEMENT
}

\author{
Irina Bilouseac ${ }^{1}$ \\ Petronela Zaharia ${ }^{2}$
}

\begin{abstract}
The problem of autonomy exists in any democratic state, being a fundamental principle which underpins the development of local government. Local collectivities activity is inextricably linked to the concept stated, local autonomy is the right of communities to solve and manage themselves public issues.

Our scientific approach aims at defining, analyzing and configuring the structural elements of local autonomy. To understand the complex meaning of autonomy in local public administration management we intend to identify the elements that form its structure and gives it consistency, i.e. organizational, functional and administrative components.

In addition, the provision and implementation of local autonomy is a goal of all European states, their constitutions assigning a primordial role to this principle, whose importance in the organization and functioning of local public administration is undeniable.
\end{abstract}

Keywords: local autonomy, local collectivities, the local administration, local public affairs, administrative decentralization

JEL Code: $H 83$

\section{Introduction. Approaches to autonomy in various sciences}

For the relevance and coherent development of this article, the scientific approach has the general objective the analysis of the principle of local autonomy to clarify its meaning in the local public administration management.

In achieving this overall objective, through the present research we propose the following specific objectives:

- Clarify the meaning of the concept of autonomy in relation to the different fields of research, such as psychology, philosophy or sociology;

- Substantiate the significance of local autonomy at European level by considering various European countries regulations;

- Examination of the composition of local autonomy, by highlighting structural elements that give its consistency.

To achieve both the general objective and the specific objectives set out above, it is necessary to specify the research methodology. Thus, in terms of research strategy, we will use the following methods of investigation: qualitative analysis, study of documents, observation, comparison, ordering, all these methods offering the possibility of studying, in a comprehensive way, the topic addressed.

A thorough explanation of the meaning of local autonomy leads us to investigate approaches coming from psychology, philosophy or sociology, especially those offered by studies in the field of public administration science.

\footnotetext{
1 „Stefan cel Mare” University of Suceava, Romania, e-mail: irinab@seap.usv.ro

2 „Stefan cel Mare” University of Suceava, Romania, e-mail: petronelaz@seap.usv.ro
} 
In the works of philosophy or psychology, autonomy is seen in connection with a wide variety of other notions, "as controversial and problematic" as follows (Fig. no. 1.):

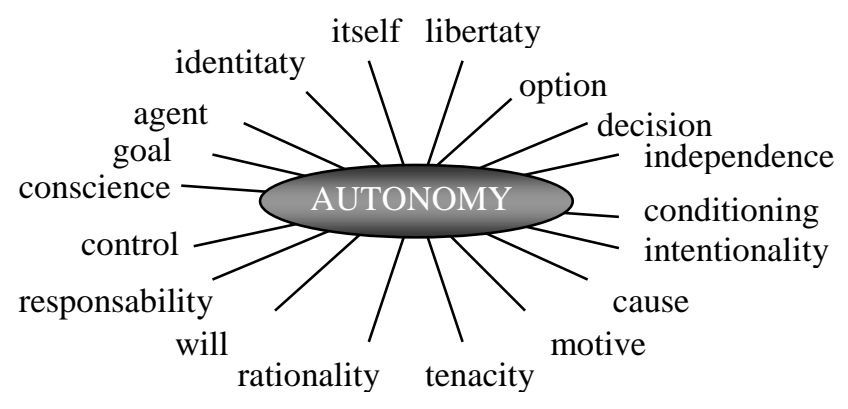

\section{Figure no. 1 - Notional categories related to autonomy}

Source: Faiciuc, 2004: 31

In the theory of psychology it is argued that is autonomous "a person able to change his life, definition which is not far from the etymological sense of the term autonomy, meaning selfgovernance, the rule under a domestic law of its own, namely the existence of an internal determinism" (Faiciuc, 2004).

Referring to the approach on autonomy into philosophical studies, we cannot ignore the concept offered by the great German philosopher I. Kant. The central idea of his moral philosophy, autonomy represents for him "the property of will through which it is a law to itself [...]". In other words, every man is a self-legislator. It also states that "generally speaking, autonomy concerns the ability of a moral self-government of the individual "(Babin).

To clarify the meaning of autonomy we ought to take into discussion a sociological view. From this direction, it is argued that "autonomy is a value shared by all societies [...]. Qualified individuals, non-autonomous or less autonomous are sidelined and considered unfortunate "(Chauffaut et al., 2003). In sociological analyzes, the concept of autonomy is equated with a person's ability to integrate into society without the assistance of third parties.

After we have looked autonomy through the senses coming from various sciences, we reach our research field, namely the local public administration. Here, "local autonomy refers to the powers and authorities belonging to communities they lead" (Voican, 2008).

With the wide support of such approach, we believe that, in a concise form, local autonomy can be seen as freedom of local authorities in the management of local problems.

\section{The concept of local autonomy in the European context}

Local autonomy is perceived in the European context as a fundamental principle governing the effective functioning of local public administration, as a component of "democratic principles common to all Member States of the Council of Europe" by regulating its legal and practical application, it makes possible the decentralization of power (Popa et al., 1998).

Protecting and strengthening of local autonomy in Europe were made by the European Charter of Local Autonomy (adopted after years of initiatives and deliberations), signed in 1985 in Strasbourg, written at the initiative of the Standing Conference of Local and Regional Authorities of Europe. The Charter contains provisions that stipulate the general principles of local autonomy and shows the need for the existence of a legal and constitutional basis of the concept of autonomy, defining the concept and establishing rules governing the organization and powers of local authorities.

Article 3 of the European Charter of Local Autonomy defines local autonomy as follows: 
„1. Local self-government denotes the right and the the effective capacity of local authorities, within the limits of the law, to regulate and manage a substantial share of public affairs under their own responsibility and in the interests of the local population.

2. This right shall be exercised by councils or assemblies composed of members freely elected by secret ballot on the basis of direct, equal, universal suffrage, and which may possess executive organs responsible to them. This provision shall in no way affect recourse to assemblies of citizens, referendums or any other form of direct citizen participation where it is permitted by statute."

To fully understand the significance of the concept of local autonomy, as reflected in the provisions of the European Charter of Local Autonomy, the following figure presents its essence (Fig. no. 2):

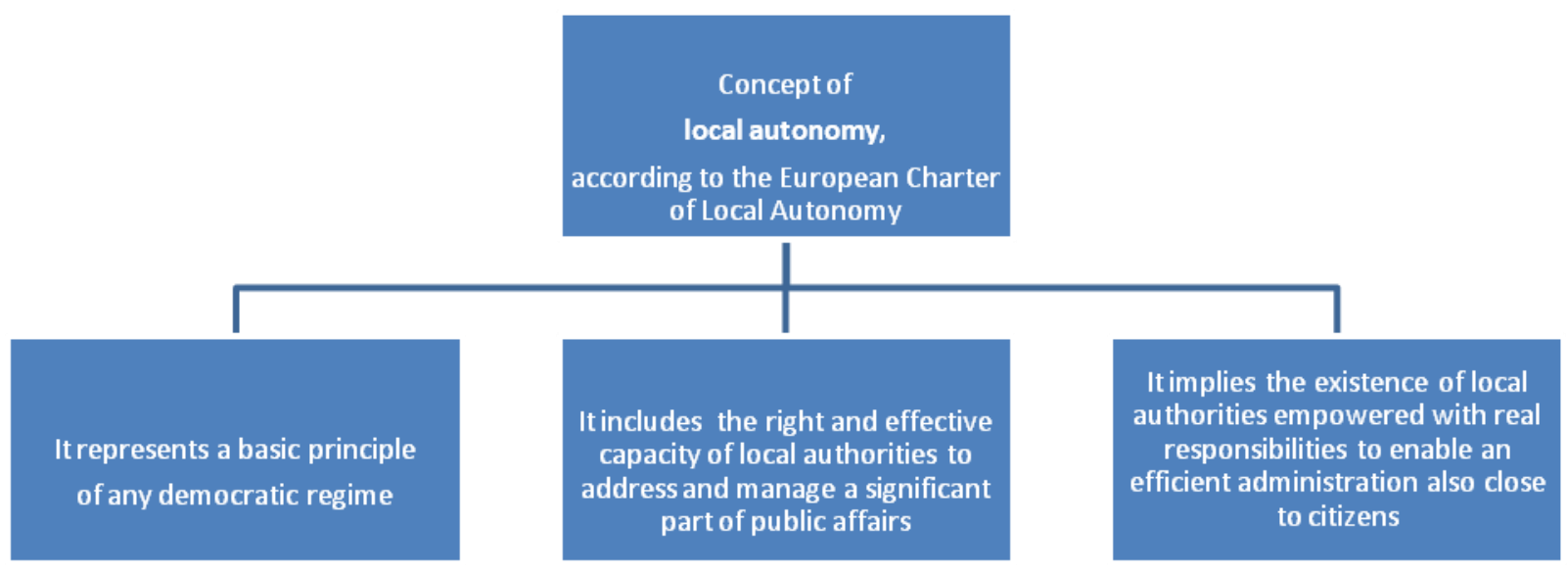

\section{Figure no. 2 - The significance of the concept of local autonomy according to the European Charter of Local Autonomy}

Through the expression "the right and the effective capacity" of local authorities, the European Charter states the idea that local autonomy is primarily the right of local authorities, which means that there must be effective capacity of self-managing in the public affairs at the local level. Therefore, to fulfill this "right", which means a theoretical granting of the local autonomy, it is also necessary to assign material and financial resources in order to achieve those rights and capacities conferred.

For our part, we share the view of Professor G. Cornea, who believes that through "local authority" the European doctrine envisages territorial administrative units (municipalities, cities and counties where local autonomy is exercised) not authorities exercising their right to the local autonomy (Cornea, 2002).

To support this idea, we note the provisions of the European Constitution, which by this expression means the commune (rural or urban).

Thus, The French Constitution of 4 October 1958 states: "Local authorities of the Republic are municipalities, departments, the overseas territories. Any other local authority is established by law. Communities freely are administered by elected councils, as provided by law (art. 72)".

Spanish Constitution of December 27, 1978 states: "The Constitution guarantees the autonomy of municipalities. They will have full legal personality. Leadership and management lies with the respective municipal councils, consisting of mayors and councilors (art. 140)".

Polish Constitution of 2 April 1997 states: "The village is the fundamental unit of local administration (article 164 paragraph 2)." "Other units of territorial self-administration and local and regional authorities are established by law (Article 164 paragraph 2)." "Local selfadministration units perform their duties through deliberative also executive authorities (art. 169 
paragraph 1)". Poland has secured very early, in March 1990, a high degree of local autonomy and cultural competence through "Territorial Governance Act".

In the Republic of Moldova the local government is based on certain fundamental principles stipulated in constitutional provisions included in art.109 and also in art. 3 of the Law on local public administration in the Republic of Moldova no. 123 - XV of 18 March 2003.The Constitution assigns a primordial role to the principle of local autonomy that underlies the organization and functioning of local authorities. Art. 7 of the Law on local public administration in Republic of Moldova provides that in exercising their powers local authorities have autonomy enshrined and guaranteed by the Constitution, by international treaties to which this country is a party, in conjunction with other laws. The state territory of Moldova is organized administratively into districts, towns and villages (art. 110 of the Constitution), the authorities through whom local autonomy in villages and towns is accomplished are local councils and mayors, and the district council coordinates the activity of villages and towns in order to achieve public services at district level.

In Romania the principle of local autonomy also knows both a constitutional regulation and legislative one. Romanian Constitution, in art.120, paragraph 1 proclaims only this principle, leaving to the organic law (as required by art. 73 paragraph 3, letter o of the Romanian Constitution) the practical regulation of this principle.

The phrase "within the law" shows that local autonomy must establish legal boundaries, i.e. local authorities' powers are subordinated to the law, without any discrimination (local autonomy is recognized by all residents of an administrative-territorial unit, without differences on social, ethnic, professional bases, etc.). In this sense, the doctrine states that "the degree of autonomy is related to all administrative units, regardless of the ethnic composition of the population. Autonomy is not the right of an ethnic community, but a political objective of governance decentralized (Deaconu,2003).

On the background of the aspects mentioned above, to note that local autonomy is experiencing a broad approach in the European context, "its defense and strengthening within various European countries representing a significant contribution to building a Europe based on the principles of democracy and the decentralization of power" as stated in the Preamble of the European Charter of Local Autonomy.

\section{Setting up the structure of local autonomy}

To understand the complex meaning of autonomy in the management of local government, further the scientific approach we will examine its composition, emphasizing its structural elements.

From such a perspective, the interpretation of the art. 4, paragraph 2 of Law no. 215/2001 on local public administration, according to which "local autonomy concerns the organization, functioning, powers and duties, but also the management of resources of the territory, city or county, as appropriate", and according with reviews (Stoica, 2010; Popa, 1991; Tudor, 2009) expressed in the literature, we consider that, in terms of structural configuration, three elements form the autonomy and give it consistency: organizational, functional and administrative.

\section{The organizational autonomy}

From an organizational perspective, autonomy is manifested in terms of three components as follows (Popa, 1991):

- The eligibility of local authorities;

- Adopting the locality statute, organizational charts and number of positions;

- Organizing public services of municipal, town, city and county councils.

The manifestation of autonomy is supported by free elections for designation by voting citizens, domiciled in the administrative-territorial unit, of leading authorities of local administrative structures, without being subject to any confirmation procedure or any interference 
coming from the center. This way of establishing local authorities highlights the residents' opportunity to nominate themselves those who act on behalf and in their interest.

Also in terms of organization, we note local authorities' powers to adopt locality status, organization charts and the number of employees. Notable in this respect are the legal provisions that include in the powers of local and county council the approval of locality status, rules of organization and functioning of the board, organization chart, and the functions of specialized apparatus, institutions and public services at the local or county level. Therefore, according to Law no. $215 / 2001$ on local public administration, the local council "approves the status of village, town or city, and the organization and functioning of the council" (art. 36 par. 3 letter a); local council "approves under the law , to the mayor's proposal, the establishment, organization and the positions of mayor's specialized apparatus, of institutions and local public services of local interest, but also the reorganization and the positions of the autonomous administrations " (art. 36 par. 3 letter b); the county council "approves the rules of organization and operation of the county council, the organization chart, the positions, the organization and functioning of specialized apparatus, but also institutions and public services of county interest, companies and autonomous administrations of county interest " (art. 91 par. 2 letter c).

The organizational autonomy is also manifested in the responsibility of village, town, city and county to organize public services for local and county interest. Local councils organize local public services in the main areas of activity, according to the specific local needs and compliance with legal provisions, in the limit of their financial resources available (article 73 of Law no. 215/2001), similar to county councils that organize public services of county interest (art. 91 par. 1 letter a of Law. 215/2001).

The examination of the autonomy from the organizational point of view would not be complete without highlighting the relationship between public authorities of communes, towns and municipalities and public authorities at the county level. As a guarantee for the manifestation of autonomy between these authorities there is no hierarchical subordination of some over others. If such subordination existed, local autonomy would suffer. Therefore, the relationship between these authorities is based on the principles of autonomy, legality, responsibility, cooperation and solidarity in solving the problems of the entire county. In the relations between local authorities and county council, on the one hand, and between the council and the mayor, on the other hand, there are no relationships of subordination (Article 6 par. 1 and 2 of Law no. 215/2001).

As shown above but in a concise way, we emphasize that the organizational autonomy refers to the ability of local governments to organize themselves according to local needs.

\section{The functional autonomy}

In terms of functional, the manifestation of the autonomy lies through the following two components (Popa, 1991):

- The plenitude of jurisdiction of municipal councils, town, city and county;

- The collegial character of the municipal council, town, city and county.

The functional autonomy is manifested primarily by competence of local authorities to solve local problems without the intervention of other authorities. The unlimited jurisdiction of local authorities in addressing and managing local public affairs derives from their recognized right to take initiatives in all areas, except for those found expressly under the jurisdiction of other authorities (art. 5 par. 2 of Law no. 215/2001). The more so as the ones that meet the needs of the community more closely are the local authorities and, consequently, they are the best placed to work towards serving local needs.

Then, from the functional point of view, the autonomy results from the collegial nature of the deliberative authorities of local government. The collegiality of municipal, town, city and county councils is the principle according to which leadership is exercised by several people who jointly adopt decisions by majority vote. Functioning of deliberative authorities of the local 
government is determined by their collegiality. In terms of functional, to take effect, adoption of a ruling needs a quorum and majority required for adopting it (Popa, 1991).

In this regard, we keep in mind that functional autonomy involves the ability of local authorities to operate on the basis of self-managing and self-governing of public affairs of the local community.

\section{The administrative autonomy}

From the administrative point of view, the autonomy is manifested by competence of local authorities to manage local patrimony for the proper performance of their powers. In other words, the administrative autonomy is based on local heritage, which is run and managed by local authorities. The latter have public and private property assets of the administrative-territorial unit and financial resources in order to serve local needs. Local authorities own and also administer buildings, land, equipment and other goods, plus funds, which they use in the interest of the local population.

In this way we emphasize that the administrative autonomy of local authorities concerns their ability to self-manage by using local patrimony in accordance with the interests of the community.

As previously mentioned and for easier reception, we present in the figure below the configuration of the autonomy, by representing each of the three elements that make up its structure (Fig. no. 3.):

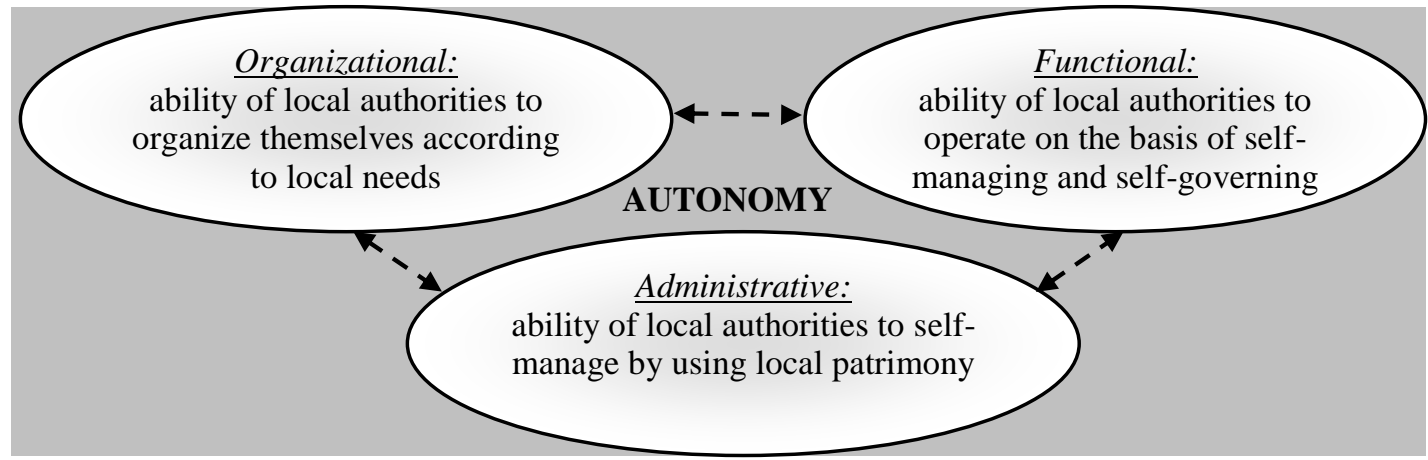

Figure no. 3 - Composition of local autonomy

Source: own elaboration

As shown in the figure above, none of these three structural elements can be seen in isolation, but together they define its configuration and provide support for autonomy in the management of the local public administration.

\section{Conclusions}

Through those presented in this article we explained the significance of the concept of local autonomy, defining principle in the organization of the public administration system according to European standards and keeping with the European Charter of Local Autonomy.

From the aspects above it follows that the functioning, the administrative methods of management, the way in which budgets of revenues and expenditures of the administrative and territorial units are approved, the institutional and legal framework at local level are all organized based on the principle of local autonomy.

But for autonomy is essential to bring together cumulatively three components: organizational, functional and administrative. Local autonomy means, on the one hand, the organization and functioning of local government, and on the other hand the management of the communities they represent. 
It should be noted that, if the first two components are easily met (there are elected authorities who have the power to solve an important part of public affairs without the intervention of other authorities), the third component, namely the administrative autonomy, is one of the most difficult problems of local autonomy. Local government must possess sufficient financial resources, so that we can speak of a real administrative autonomy.

Therefore, the concept of autonomy is complex, and its evolution over time will depend on how the understanding of the contents of this principle and its concrete application will be performed through practical actions in each administrative-territorial unit.

Overall, the approach developed in the previous pages allows highlighting of some personal contributions to the knowledge of the research field, resulting as follows:

- Systematization of conceptions regarding autonomy by clarifying the meanings coming from psychology, philosophy or sociology;

- Developing a conceptual basis of autonomy by considering various European regulations;

- Explain the composition of local autonomy through the structural elements that ensures its operation;

- Substantiate the principle of autonomy by clarifying the significance it has in the field of management of local public administration.

Finally, the conclusion that emerges from the analysis of the principle of local autonomy is that it entails administrative decentralization and thus it supposes to transfer powers from central to local level, where local autonomy provides a high degree of democracy, being one of the most effective forms allowing self-government and local self-management.

\section{References}

1. Babin D., Kant şi autonomia voinţei, Revista Hiperboreaa, nr. 2, available online at http://revistahiperboreea.com/kant-si-autonomia-vointei / [accessed on February 7, 2014]

2. Chauffaut D., David E., Aldeghi I., Cohen-Scali V., Mahe T., Bouscasse M., 2003. La notion d'autonomie dans le travail social, Centre de Recherche pour l'Etude et 1'Observation des Conditions de Vie, Cahier de Recherche, $\mathrm{n}^{\circ} 186$, available online at http://www.credoc.fr/pdf/Rech/C186.pdf [accessed on February 10, 2014]

3. Constitution of Romania, published in Official Gazette no. 767 of October 31, 2003

4. Constitution of the Republic of Moldova, published in the Official Gazette of the Republic of Moldova no. 1 of 18.08.1994, as amended

5. Cornea, G, 2002. Discuţii şi aprecieri critice în legătură cu principiul autonomiei locale in România, Revista Dreptul, nr. 10/2002, Bucureşti

6. Deaconu Ş., 2003. Bună guvernare şi descentralizare, Revista de Drept Public, nr. 3/2003, Bucureşti

7. European Charter of Local Self-Government, adopted in Strasbourg on October 15, 1985

8. Faiciuc L., 2004.Comportamentul autonom: fantoma de la Operă, Anuarul Institutului de Istorie "George Bariţiu" din Cluj-Napoca, Series Humanistica, tom. II, available online at http://www.humanistica.ro/anuare/2004/Anuare\%202004/Art.03.pdf [accessed on February 5, 2014]

9. French Constitution of 4 October 1958

10. Law on local public administration no. 215/2001, republished in the Official Gazette no. 123 of 20 February 2007, as amended

11. Law no. 123 - XV on local government in the Republic of Moldova, Chisinau, March 18, 2003, published in Official Gazette 49 of 19.03.2003

12. Polish Constitution of 2 April 1997 
13. Popa E., 1991. Autonomia locală în România, Editura All Beck, Bucureşti

14. Popa V., Munteanu I., Mocanu V., 1998. De la descentralism spre descentralizare, Editura Cartier, Chișinău

15. Scutariu A. L., 2013. The influence of E.U. integration on the overall development in the regions North-East of Romania, Subcarpathia of Poland and Central Slovakia, The USV Annals of Economics and Public Administration, Volume 13, Issue 1(17)

16. Spanish Constitution of December 27, 1978

17. Stoica I., 2010. Managementul administraţiei publice, Editura Sitech, Craiova

18. Tudor F., 2009. Consolidation of fiscal decentralization and financing of local authorities, Public Administration \& Regional Studies, $2^{\text {nd }}$ Year, No. 1, Galati University Press

19. Voican M., 2008. Principiile cadru ale administraţiei publice locale, Editura Universul Juridic, Bucureşti

20. Zaharia P., 2013. Autonomia în managementul administraţiei publice locale, Teză de doctorat, Universitatea „Al. I. Cuza” Iaşi. 